\title{
Religious and Heritage Education in Israel in an Era of Secularism
}

\author{
Yaacov J. Katz ${ }^{1,2}$ (D) \\ 1 School of Education, Bar-Ilan University, Ramat-Gan 529002, Israel; yaacov.katz@biu.ac.il; \\ Tel.: +972-525-992-727 \\ 2 Michlalah-Jerusalem Academic College, Jerusalem 9642845, Israel
}

Received: 4 September 2018; Accepted: 12 October 2018; Published: 19 October 2018

\begin{abstract}
Israel as a unique country composed of a religiously heterogeneous society of native-born Israelis whose parents arrived in the country before the declaration of Israel as an independent state in 1948 and immigrant Jews coming from countries spread throughout the world, mainly from the early 1960s until the present time, as well as Arab Moslem, Arab Christian, and Druze citizens born in the country. The Jewish population consists of secularized Jews who are almost totally estranged from the Jewish religion; traditional Jews who identify with the Jewish religion; religious modern orthodox observant Jews who share common societal goals with members of secular and religious Jewish society; and religious ultra-orthodox observant Jews who are rigid in their faith and oppose absorption and assimilation into general society. The Israeli Arab population comprises Moslems who are generally more religious than Israeli Jews, but are less religious and more flexible in their religious beliefs than Moslems living in many other countries in the Middle East. Christians who identify with their religion; and a moderately religious Druze community. Because of the heterogeneity of Israeli society, mandatory religious and heritage education presents each sector with a unique curriculum that serves the particular needs considered vital for each sector be they secular, traditional, or religious. In order to offset the differences in religious and heritage education and to enhance common social values and social cohesion in Israeli society, citizenship education, coupled with religious and heritage education, is compulsory for all population sectors.
\end{abstract}

Keywords: state Jewish religious education; state Jewish secular education; state Arab Moslem education; state Christian education; state Druze education; religious and heritage education; citizenship education

\section{Background}

According to the description presented by Katz [1], Israel as a unique country with a population that has increased by $1000 \%$ since independence in 1948 and is made up of a multi-cultural, multi-ethnic, and religiously heterogeneous society of native-born Israelis whose parents arrived in the country before the declaration of Israel as an independent state in 1948 and immigrant Jews hailing from countries throughout the world, as well as Arab Moslems, Arab Christians, and Druze largely born in the country [2]. The breakdown in the demographics of the Israeli population of approximately 8.5 million is presented in Table 1: 
Table 1. Demographics of Israeli Population [2].

\begin{tabular}{cc}
\hline Sector & Percentage \\
\hline Jewish Secular & $40 \%$ \\
Jewish Traditional & $23 \%$ \\
Jewish Orthodox & $10 \%$ \\
Jewish Ultra-Orthodox & $8 \%$ \\
Moslem & $14 \%$ \\
Christian & $2 \%$ \\
Druze & $2 \%$ \\
No religion & $1 \%$ \\
Total & $100 \%$ \\
\hline
\end{tabular}

The influx of immigrants from Europe and North America brought about a rapid transition to modernity and secularism in some sectors of Israeli society on the one hand while the mass absorption of immigrants from North African and Asian countries contributed to the maintaining of tradition and religiosity in other sectors of Israeli society on the other. As such, the Israeli population may be described as being both traditionally religious as well as secular with traditionally religious citizens living amicably alongside citizens who have adopted a secular way of life [3]. Traditional societies differ from modern, and especially postmodern, societies most especially on the issue of coherence, cohesion and homogeneity which are perceived to be of major importance in traditional societies as opposed to the philosophy that emphasizes the importance of individualization, heterogeneity and social flexibility of modern and postmodern societies and communities.

The Israeli Jewish population [4] consists of a number of societal sectors broken down as follows: secularized Jews who are members of the Jewish faith by birth but totally estranged from the Jewish religion by conviction and ideology; traditional Jews who consider themselves as being members of the Jewish religion but usually do not fulfill Jewish religious demands, precepts, and commandments; orthodox Jews who strictly observe Jewish tradition, precepts, and commandments but believe that they share common societal goals with members of secularized, traditional as well as religious Jewish society and strive for integration and assimilation into Jewish society in their daily lives; and ultra-orthodox Jews who rigidly observe religious traditions, precepts, and commandments and oppose integration into general society in the belief that partnership with the other sectors in Israeli society will negatively compromise their beliefs and religious lifestyle.

The Israeli Arab population [5] includes a large sector of Moslems who are moderately religious and flexible in their level of religious observance despite a visible trend towards increased levels of religious fundamentalism; a much smaller but vibrant sector of members of the Christian faith who maintain a moderate and pragmatic attitude towards their religiosity and mainly view their faith as being an essential part of their social identity as well as their culture; and an even smaller Druze community which also maintains a strong affiliation with Druze history, Druze identity, and Druze culture as well as with the secret Druze religion with only the clergy actually having full knowledge about the intricacies of the religion. The Israel Ministry of Education is aware of the significant heterogeneity of Israeli society and while religious and heritage education is mandatory for all sectors in Israeli society, each individual sector is free to set a unique curriculum that serves its beliefs, ideology, identity, and culture.

This paper will address the complex issue of state religious and heritage education within Israeli society that prides itself as being secular, democratic, modern, humanistic, and universalistic. The paper will explain how the core concepts of religion, heritage, national identity, national history, and natural culture, vital to the existence of Israel as a Jewish state, entrench the values of democracy, equality, social harmony, humanism, and universalism that significantly contributes to coherence and cohesion for all members of Israeli society. Thus, the paper will examine the effect of religious and heritage education on students in schools in the Jewish (religious-orthodox and secular) sectors and Arab (Moslem, Christian, and Druze) sectors vis-à-vis religious influence and social cohesion that 
reflects their respective religious denominations, identities, history, and culture. Note should be made that this paper analyzes religious and heritage education in state schools only and not in private or semi-private schools, such as those in the ultra-orthodox sector, that are autonomous and not totally bound by the mandatory curricular requirements set by the Ministry of Education.

\section{The Importance of Social Cohesion in Israel}

David Ben-Gurion, the first Israeli Prime Minister and the other leaders of the fledgling independent Israeli state, instituted national policy [6] whereby state institutions, such as the Israel Defense Force and the state education system, serve as social melting-pots and proponents of enhanced social integration of the different religious, cultural, ethnic, and national groupings into a predominantly homogeneous society. This policy was implemented in the early days of Israeli independence and, at the time, was best suited to the nature of traditional society of the 1950s and 1960s. However, since the 1960s, Israeli society began to develop as a typical western democracy and shied away from the tradition of socialism and gravitated towards the enhancement of individual civil rights alongside the rights of the collective. Concern for the individual and for the need to promote the rights the different sectors of a heterogeneous society became a major societal goal, and the enhancement of unique religious, cultural, ethnic, national, and different value-based agendas has become increasingly tolerated and acceptable in Israeli society. Since the late 1960s and the early 1970s, the different sectors in the Israeli population have become more aware of the need to actively realize their unique sectorial demands. As result the respective sectorial groups in Israel have actively campaigned for a radical change in society and have been successful in engineering a transformation of Israeli society from one where the more traditional homogeneous values of cohesion and integration to one where different sectoral and group values have become acceptable, normative and even desirable.

As a result of the abovementioned social changes that have transpired in Israeli society since the 1990s, namely the move from traditional social homogeneity to heterogeneous secularism, modernism, and postmodernism, different perceptions of religiosity, culture, values, and education are now those that significantly characterize contemporary Israeli society. The different sectors in Israeli society have chosen to accentuate these differences at the expense of social cohesion and social harmony that typified Israeli society from the early days of independence up till the 1990s. Thus, the modern and post-modern divides in Israeli society that have developed in recent years and the resulting tensions and acrimony between the different societal sectors have led to a concerted move by the Israeli leadership to initiate moves to renew social cohesion and social harmony in Israeli society mainly through proactive introduction of mandatory religious and heritage education throughout the Israeli state school system.

\section{Education for Social Cohesion in Israel}

A major goal of Israeli society is to expend major efforts to minimize and limit inter-religious, inter-ethnic, inter-national, and inter-cultural gaps between different sectors in the population, and to generate the acceptance of common social values and cohesion in a society that may be described as extremely heterogeneous and sectorial [7]. The education system in Israel has made gradual progress in an attempt to promote and enhance values designed to lead to social cohesion. There is a general consensus among political as well as educational leaders that religious and heritage education as well as citizenship education are the main vehicles and platforms for the enhancement of social cohesion in Israel. In addition, there is agreement that religious and heritage education together with citizenship education need to emphasize the notion that Israel is a Jewish and democratic state, and that education must substantially contribute to the narrowing of differences and schisms between the different societal groups in order to facilitate coherence in society as well as the development of intrinsic values that vitally permeate a normative Jewish and democratic state.

Education for social cohesion and values has become a major mandatory feature of Israeli education and is mandatorily provided within the domain of religious and heritage education 
complemented by citizenship education $[8,9]$. All students in the state education system now study religious and heritage education as well as citizenship education as complementary mandatory core subjects. Both subjects include references to the promotion of religious tradition as well as social cohesion and call for the intensification of democratic, egalitarian humanistic and universal values among students [10].

\section{State Education in Israel}

The Israeli Ministry of Education is endowed with the largest budget allocated to a civilian ministry and is second only to that of the Ministry of Defense. The resources that are earmarked for education enable the school system to develop necessary educational facilities, school-based technology, teaching pedagogies and learning methods as well as a variety of extra-curricular programs for students at all levels in the school system [11]. The educational and professional qualifications of teachers in Israel is acceptable by international standards [10] with almost all teachers in the education system in possession of a college degree and a teaching diploma. School facilities, such as classrooms, libraries, laboratories, computer rooms, and sports facilities are well developed; the achievement of students in school-leaving matriculation and university-entrance examinations is, on the average, similar to the level of achievement characterizing matriculants and school-leavers the average Western country; the average drop-out rate of students is low and, in general, parents increasingly express an interest in their children's education.

The Israeli education system is similar in its structure to that typifying schools in most western countries and offers mandatory and free state education to all students. There are approximately 2 million students attending preschools, elementary schools, junior high schools and high schools that are divided into two major sectors, namely Jewish and Arab. The two sectors are administered by independent departments in the Israeli Ministry of Education and enjoy sectorial autonomy with inspectors, who belong to the different sectors, responsible for supervising the educational process in each sector. The Ministry of Education is responsible for the curriculum, examinations, and teacher certification of all sectors and coordinates the educational processes that are implemented in schools affiliated to the different sectors.

Religious and heritage education as well as citizenship education are mandatory subjects studied by all sectors in the Israeli population $[12,13]$. Students belonging to all major religious denominations in Israeli society (Jewish, Moslem, Christian, and Druze denominations) are required to study their own unique religious traditions and heritage as well as to study common values such as democracy, equality, social harmony, humanism, and universalism that are perceived to contribute to the enhancement of social cohesion. Because of the importance of religious and heritage education in the different sectors of the education system and the uniquely differential needs of the different sectors in these areas, the national education budget provides differential financial resources to cover the costs of the different religious and heritage education curricula provided by the different sectors in the education system.

In order to understand the aims of religious and heritage education in the Israeli education system, especially with regard to the expected contribution to social cohesion and commonly accepted social values, it is vital to understand the educational format and framework within which religious and heritage education complemented by citizenship education is delivered to both Jewish and Arab school-going populations. Following is a description of this framework [14].

\section{State Jewish Education in Israel}

The Jewish education system in Israel is granted budgetary resources by the central government augmented by additional finances provided by local municipal authorities that permit widespread development of school facilities, up-to-date technology, up-to-date teaching pedagogies, and learning methods, and a variety of extra-curricular programs for students at all levels in the school system [11]. The structure of the state Jewish education system in Israel includes state religious and state secular sub-sectors each catering respectively to parents and their children who are ideologically motivated 
to send their children to religious or secular schools. Students in the sub-sectors are presented with identical learning content and curricula in most subjects except for those where ideology dictates necessary differences [6]. Thus, the curricula of subjects such as Hebrew, English, mathematics, science, geography, and physical education, are identical in both sectors. However, the curricula of subjects such as literature, history, art and especially religious and heritage education, that contain ideologically sensitive content are specifically designed according to the unique needs of each sector.

\section{Jewish Religious and Heritage Education in Israel}

In the mandatory core curriculum implemented in Israeli schools [15], religious and heritage education complemented by citizenship education are major core subjects studied by students in the two main Jewish educational sectors. Because of public dissatisfaction with the state of religious and heritage education in the Jewish school system, the then Minister of Education appointed the Shenhar Commission [12] to examine how best religious and heritage education could be implemented in Jewish schools. The report of the Shenhar Commission affirmed the vital necessity of introducing religious and heritage education as a compulsory subject in the core curriculum for the Jewish school population. At the same time serious public criticism concerning a lack of social cohesion in Israeli society as well dissatisfaction with the study of democratic, ethical, and social values in Israeli schools was voiced and the Minister of Education appointed the Kremnitzer Commission [13] to recommend how vital democratic, ethical, and moral values could and should be implemented Jewish schools within the mandatory core subject of citizenship education. The report of the Kremnitzer Commission affirmed the need to intensify the study of citizenship education in all Israeli schools, most especially, with regard to the emphasis on democracy, equality, social harmony, humanism, and universalism.

After the publication of the reports of the Shenhar and Kremnitzer Commissions, a department was established within the Ministry of Education to oversee the implementation of religious and heritage education on the one hand, and complementary citizenship education on the other in Jewish schools. The pedagogical strategy of implementation called for as much congruence and integration as possible between religious and heritage education and citizenship education so as to ensure that the subject matter taught in both domains would be coherent and complementary. Thus, the new department that dealt with the implementation of both subjects into the mandatory core curriculum closely worked as one team on the contents and pedagogics of both subjects.

\subsection{Religious and Heritage Education in the State Religious Sector}

The raison d'etre of state religious and heritage education is to enhance and deepen students' religious belief, deportment and knowledge of Jewish tradition as well to intensify students' responsibility towards the public and to the needs of others [16]. The study of religion in state religious schools is also expected to address problems that affect religious belief that in certain circumstances conflicts with moral and ethical domains [17]. Furthermore, religious and heritage education in the state religious school system is designed to intensify Jewish religious belief, tradition, and morality and prepare students for acceptance of the normative needs of society [18]. Thus, in the religious educational sector alongside the religious nuances that characterize the religious and heritage education curricula, common moral, ethical, and cultural values are mandatorily taught and student well-being is promoted and enhanced.

According to the National Education Act legislated in 1953, parents have the right to choose the educational sector in which their children will be educated. Thus, parents who choose the state religious sector for their children do so mainly because they feel that the focal feature of their children's education is the religious emphasis placed on all facets of cognitive and affective achievements in this sector [14]. In state religious and heritage education, emphasis is placed on faith and knowledge-based education where religious and heritage education consists of a range of religious subjects that are taught from a deterministic religious point of view and is designed to ensure religious observance of precepts and commandments as well to ensure scholastic achievement in the other core subjects (such 
as Hebrew, English, mathematics, science, history, citizenship) in matriculation examinations taken by students at the end of their school careers. Citizenship values that contribute to societal cohesion and are congruent with religiosity, such as such as democracy, equality, social harmony, humanism, and universalism are part and parcel of students' vital education and teachers are fully aware of the focal importance of religion in the values presented to the students [19]. Thus, teachers are fully motivated to inculcate religious observance in their students' deportment and perceive Western-oriented citizenship values through the sectoral religious Jewish prism.

\subsection{Religious and Heritage Education in the State Secular Sector}

The ethos and vision of the state secular education system in Israel include the inculcation of values and morals as well as good citizenship that are an integral part of the development of a unique Israeli culture [20]. According to this perception, the aim of secular schools is to enhance a value system that encompasses aims, goals, culture, knowledge, skills, and feelings that contribute to the development of norms unique to a modern or post-modern society. Thus, values education is perceived as that segment of the educational process that is concerned with the development of culture, values, beliefs, attitudes, feelings, and emotional well-being of students. As such, the term 'culture' in the state secular school system displaces the term 'religious belief' in state religious schools.

There are three major concepts underlying religious and heritage education offered in state secular schools in Israel [21]. The concepts 'acquired truth', 'freedom of thought', and 'modern' indicate the basic foundations on which the philosophy of secular education in Israel is built. Truth is dependent on the acquiring of knowledge, which in turn is strengthened and intensified through the freedom and originality of thought. The study of the modern versus the traditional influences motivates students to adopt a values system congruent with humanistic perceptions of the world. Religious belief, is regarded by the state secular school system to be superfluous and out of touch with modern or post-modern reality. The needs and the spirit of free inquiry, based on Jewish cultural and historical sources as well as on universal culture, rather than convergent thinking based on traditional and religious sources, is that which leads to the development and adoption of normative secular values and morals. In the state secular school system, religious and heritage education is totally knowledge-based and addresses Jewish history, culture, and identity without any reference to religious deportment or behavior [1]. In addition, citizenship values based on Jewish tradition as well as on Western-oriented morals and ethics are emphasized in religious and heritage education in this sector.

Parents choose this sector mainly because they are secular in their personal outlooks and perceptions and have no religious commitment. They wish to ensure that their children experience a well-rounded and balanced secular education that emphasizes scholastic achievement as well as citizenship based on democracy, equality, social harmony, humanism, and universalism without any reference at all to religious observance or religious lifestyle. Students are encouraged to study in order to attain high levels of scholastic achievement that will enable them to obtain quality matriculation and school-leaving grades. Thus, religious and heritage education in this sector emphasizes the study of Jewish history, Jewish culture, and Jewish identity without referring to the practical observance of religious precepts. In this sector there is a clear distinction made between the importance of acquiring objective knowledge about the Jewish religion and heritage on the one hand, and total resistance to religious and heritage education being a springboard to an increase Jewish religious observance on the other. In addition, values that enhance social cohesion and pervade the citizenship values of democracy, equality, social harmony, humanism, and universalism are the major topics that characterize religious and heritage education in this sector.

\section{State Arab Education in Israel}

The structure of the state Arab education system in Israel is rather like an umbrella authority for a number of Arab population sub-sectors (Moslem, Christian, and Druze) [22]. The governmental budgetary resources complemented by financial resources provided by local Arab municipal authorities 
to schools in this sector are officially identical to the budgets provided to schools in the Jewish sector. Students in the sub-sectors are presented with similar learning content and curricula in secular subjects (Arabic, English, mathematics, history, and geography) as offered to students in the Jewish state secular schools. However, religious and heritage education is designed to enhance knowledge about the unique basic beliefs and foundations of Islam, Christianity, and the Druze religion, and is offered to the students according to their particular religious affiliation.

Note should be made of the shortcomings that typify the Arab education system. Although Arab education is financed by the Ministry of Education and the local Arab municipal authorities in line with the same criteria that dictate the budget allotted to Jewish education, benign neglect by successive Israeli governments has produced inequality in allocation of resources between Jewish and Arab schools [23]. As a result, parents are critical of the Arab education system and are assertive in their demands that the Ministry of Education must provide additional resources to Arab schools in order to close the quality gap between the Jewish and Arab educational sectors. The Ministry has embarked upon a policy of improving the allocation of resources to the state Arab educational system and recently earmarked a special state budget in order to effect measures designed to close the existing gap in the level of education provided in Jewish and Arab schools.

\section{Arab Religious and Heritage Education in Israel}

Unlike the Jewish educational sector, the Arab educational sector includes students who are both religious and secular. They usually study in the same schools although there are schools available for Arab students who belong to the different national and religious denominations (Moslem, Christian, and Druze) and particularly wish to study in a religiously denominational school. Within Arab schools religious and heritage education is provided to the different denominationally oriented sub-sectors of the Arab student population (Moslem, Christian, and Druze) with emphasis on the unique aspects of the different religious denominations as well as the common aspects of culture, tradition, morals, and values that pervade Israeli society. It should be noted that the different sub-groups in Arab society are rather indifferent to the issue of religious and heritage education in the state educational system and prefer private religious frameworks such as complementary mosque or church-based educational centers that are clearly to be more efficient providers of religious and heritage education to all children whose parents are positively in favor of religious education [1]. Despite these shortcomings, religious, and heritage education is mandatory in all state Arab schools just as it is in all state Jewish schools.

\subsection{Religious and Heritage Education in the State Moslem Sector}

In the state Moslem educational sector, students study a similar range of subjects studied in Jewish schools. This provides them with the necessary knowledge and standards required to successfully cope with the demands of the matriculation examinations at the end of their school careers [24]. Religious and heritage education in this sector is focused on the Moslem tradition and provides students with a sound basic knowledge of the history, culture and observances of Islam. No confessional demands are made regarding observance of religious tradition, precepts, and commandments and students are not required to actively adopt religious practices and deportment. However, it is customary within the Moslem population Moslem to consider themselves to be positive towards Islam in their general lifestyles and are willing to accept Moslem religious tradition as one to be prized and nurtured. Religious and heritage education as studied by students in school is perceived by many in the Arab Moslem population somewhat as a catalyst that may well lead to intensified religious observance, but there is a large segment in the Moslem population that perceives religious and heritage education to be part of broad Arab culture and history rather than a subject that is designed to narrowly focus on religious observance. In addition, religious and heritage education in this sector is considered to be related to citizenship education and to contribute to the enhancement of important normative values such as democracy, equality, social harmony, humanism and universalism that will hopefully lead to social cohesion and enhanced integration of the Moslem population in broad Israeli society. 


\subsection{Religious and Heritage Education in the State Christian Sector}

In Christian Arab education in Israel parents and students are generally positive towards religion, but their life perceptions and attitudes are more secular than those characterizing the Moslem sector of the population [25]. As a result, major emphasis is placed by both parents and students on the study of secular subjects that will enhance the chances of students to successfully negotiate school leaving matriculation examinations and provide them with the opportunity of being awarded quality matriculation certificates at the end of their school careers. Religious and heritage education is perceived by Christian parents and students to be inherently related to the study of Christian culture, history and identity, and as such, is an additional and complementary facet of the citizenship education curriculum. Thus, religious and heritage education is designed to educate students towards the acceptance of traditional Christian values on the one hand and the citizenship values of democracy, equality, social harmony, humanism, and universalism as a springboard for integration in the multi-faceted Israeli society without emphasizing acceptance of religious belief or ideology.

\subsection{Religious and Heritage Education in the State Druze Sector}

The Druze educational sector maintains close reciprocal relations with the Arab sector because of the fact that Arabic is the language of instruction in both Arab and Druze systems; and the curriculum of the Druze educational subsystem is almost identical to that of the Arab education system [26] but deviates from it in the field of religious and heritage education where the unique Druze religious heritage is emphasized. This emphasis is quite limited as the Druze religion is secret and only religious leaders are fully aware of the theology, principles, and tenets of the religion. The lay Druze population is made aware of the public precepts and commandments of the religion but are totally unaware of the theology of the religion. Thus, religious and heritage education in the Druze sector is mainly concerned with unique Druze culture and traditions and is less focused on the Druze religion per se. Additionally, this leads to a much more central focus on citizenship education where the study of the societal values of democracy, equality, social harmony, humanism, and universalism is emphasized so as to contribute to the enhancement of the integration of the Druze population in heterogeneous Israeli society.

\section{Conclusions}

There is general agreement that religious and heritage education offered in schools serving all religious, national and social sectors in the Israeli school system is the relevant platform for the enhancement of unique sectoral reference to the different religious traditions present in Israeli society. Each sector and denomination studies its own particular religion with an emphasis on sectoral needs. Bearing in mind the fact that Israeli society is heterogeneous and includes both religious and secular Jewish and Arab population sectors, each sector autonomously and flexibly addresses religious and heritage education.

Thus, in the Jewish state religious sector religious belief and observance are of paramount importance; in the Jewish state secular sector knowledge about Jewish tradition, history, and culture is the focus of religious and heritage education; in the Arab state Moslem sector the tenets of Islam are taught without stressing that students become observant Moslems; in the Arab state Christian sector Christian tradition and history is taught without the issue of faith being emphasized; and in the Arab state Druze sector the basics of what is a secret religion is imparted to students without divulging the specifics of the religion. However, issues that are central to social cohesion in Israel are addressed in citizenship education which is strongly complementary to the religious and heritage education of all sectors in Israeli state education. Despite the different and unique perceptions of religious and heritage education in the state Jewish and state Arab sectors, there is agreement that the study of citizenship education is necessary to complement religious and heritage education and emphasize consensual values such as democracy, equality, social harmony, humanism, and universalism that are the basis and foundation for social cohesion and integration in heterogeneous Israeli society. 
Funding: This research received no external funding.

Conflicts of Interest: The author declares no conflict of interest.

\section{References}

1. Katz, Y.J. Religious encounters in Israeli state education. Relig. Educ. 2017, 112, 329-333. [CrossRef]

2. Sahgal, N.; Cooperman, A. Israel's Religiously Divided Society; Pew Research Center: Washington, DC, USA, 2016.

3. Eisenstadt, S.N. Comments on the post-modern society. In Israel towards the Year 2000; Lissack, M., Knei-Paz, B., Eds.; Magnes Press: Jerusalem, Israel, 1996; pp. 19-27.

4. Guttman, E. The religious divide. In Israel towards the Year 2000; Lissack, M., Knei-Paz, B., Eds.; Magnes Press: Jerusalem, Israel, 1996; pp. 61-73.

5. Abu Asba, K. Arab Education in Israel: Dilemma of a National Minority; Florsheimer Institute for Policy Research: Jerusalem, Israel, 2007.

6. Katz, Y.J. The state approach to Jewish and non-Jewish education in Israel. Comp. Educ. 2010, 46, 325-338. [CrossRef]

7. Katz, Y.J.; Yablon, Y.B. Can internet technology promote inter-group attitudes towards equality, understanding, tolerance and coexistence. In Education of Minorities and Peace Education in Pluralistic Societies; Iram, Y., Wahrman, H., Eds.; Praeger: Westport, CT, USA, 2003; pp. 169-179.

8. Katz, Y.J. A values-based core curriculum: The Israeli perspective. Panor. Int. J. Comp. Relig. Educ. 2002, 14, 117-124.

9. Ministry of Education. 100 Concepts on Judaism, Zionism and Democracy; Ministry of Education Publications Office: Jerusalem, Israel, 2003.

10. Katz, Y.J. The Israeli school core curriculum and matriculation examinations: An attempt to set standards for a national educational system. Educ. Pract. Theory 2005, 27, 67-82. [CrossRef]

11. Gaziel, H. Educational policy in Israel: Structures and processes. In Fifty Years of Israeli Education; Peled, E., Ed.; Ministry of Defense Press: Tel-Aviv, Israel, 1999; pp. 67-84.

12. Ministry of Education. People and World: Jewish Values in a Global Society; Ministry of Education Publications Office: Jerusalem, Israel, 1994.

13. Ministry of Education. To Be Citizens; Ministry of Education Publications Office: Jerusalem, Israel, 1996.

14. Katz, Y.J. State religious education in Israel: Developmental trends in the Zionist era. In Education as a Social Challenge; Gross, Z., Dror, Y., Eds.; Ramot Publishing House: Tel-Aviv, Israel, 2004; pp. 73-83.

15. Katz, Y.J. The core curriculum in Israel: an educational common denominator for all population sectors. In Towards an Educational Revolution; Inbar, D., Ed.; Van Leer Institute and Hakibbutz Hameuchad Publishing House: Jerusalem, Israel, 2006; pp. 186-194.

16. Volbe, S. The modern theological academy (yeshiva). In Religious Education in Israeli Society; Bar-Lev, M., Ed.; Hebrew University Press: Jerusalem, Israel, 1986; pp. 123-128.

17. Urbach, E.E. The religious high school: an educational trend. In Religious Education in Israeli Society; Bar-Lev, M., Ed.; Hebrew University Press: Jerusalem, Israel, 1986; pp. 131-146.

18. Bar-Lev, M. The cultural conflict of youth in yeshiva high schools. Niv Hamidrashia 1985, 242-248.

19. Katz, Y.J. Values education in the Israeli educational system. In Learning beyond Cognition; Kryger, N., Ravn, B., Eds.; Danish University of Education Press: Copenhagen, Denmark, 2007; pp. 291-302.

20. Aloni, N. Cultural education in a multi-cultural society. Matzav Ha'Inyanim 1997, 7, 3-6.

21. Eisenberg, Y. On three tensions in religious education. Dapim 1989, 8, 38-40.

22. Arar, K. Israeli education policy since 1948 and the state of Arab education in Israel. Ital. J. Sociol. Educ. 2012, 1, 113-145.

23. Glaubman, R.; Katz, Y.J. The Bedouin Community in the Negev: Educational and Community Characteristics; Research Report Number 11; Institute for Community Education and Research, School of Education, Bar-Ilan University: Ramat-Gan, Israel, 1998.

24. Sa'ar, A. Carefully on the margins: Christian Palestinians in Haifa between nation and state. Am. Ethnol. 1998, 25, 215-239. [CrossRef] 
25. Al Haj, M. Education, Empowerment, and Control: The Case of the Arabs in Israel; State University of New York Press: New York, NY, USA, 1995.

26. Court, D.; Abbas, R. Role of Druze high schools in Israel in shaping students' identity and citizenship. Educ. Citizensh. Soc. Justice 2010, 5, 145-162. [CrossRef] 